\title{
Studies on succession of insect pest complex and their natural enemies in pigeonpea [Cajanus cajan (L.) Millsp.]
}

\author{
U.A. PAWAR ${ }^{* 1}$, P.S. CHINTKUNTALAWAR ${ }^{1}$ AND T.B. UGALE ${ }^{2}$
}

${ }^{1}$ Department of Agricultural Entomology, K.K. Wagh College of Agriculture, NASHIK (M.S.) INDIA

${ }^{2}$ Department of Agricultural Entomology, Jawaharlal Nehru Krishi Vishwa Vidyalaya, JABALPUR (M.P.) INDIA

\section{ARITCLE INFO}

Received : 24.03 .2014

Revised : 24.07 .2014

Accepted : 08.08 .2014

\section{KEY WORDS :}

Pigeonpea, Key pest, Predator, Insectivorous bird

*Corresponding author:

Email: udaypawar91@gmail.com

\begin{abstract}
A field experiment was conducted at experimental field of Department of Entomology, Live Stock Farm, Adhartal, J.N. Krishi Vishwa Vidyalaya, Jabalpur (M.P.) during Kharif season 2009-2010. Thirteen different species of insects and one insectivorus bird species were recorded on the pigeonpea at Jabalpur during 2009-2010. Data collected reveled that fauna belonging to seven orders and fourteen families were associated with the pigeonpea crop. The first group of insects included jassid, leaf webber, tussock caterpillar and red pumpkin beetle which appeared when the crop age was about 39 days old i.e. during vegetative stage and remained available upto the reproductive stage. The next group of insects to appear on the crop were jassid, thrips, blister beetle, pod bug, gram pod borer, pod fly, green stink bug and red gram plume moth. These appeared when the crop age was about 102 days old i.e. at the reproductive stage and remained available upto the maturity of the crop. These pests were the major key pests which caused colossal yield losses. The natural enemies observed were lady bird beetle and a parasitic wasp Cotessia $(=$ Apanteles $)$ sp. which remained active from vegetative to reproductive stage of the crop. An insectivorous bird, black drongo was also observed to feed on different stages of insect pests infesting pigeonpea during the entire crop growth period.
\end{abstract}

How to view point the article : Pawar, U.A., Chinkuntalawar, P.S. and Ugale, T.B. (2014). Studies on succession of insect pest complex and their natural enemies in pigeonpea [Cajanus cajan (L.) Millsp.]. Internat. J. Plant Protec., 7(2) : 318-324. 